Article

\title{
Visibility Driven Perception and Regulation of Air Pollution in Hong Kong, 1968-2020
}

\author{
Peter Brimblecombe
}

Citation: Brimblecombe, P. Visibility Driven Perception and Regulation of Air Pollution in Hong Kong, 1968-2020. Environments 2021, 8, 51 . https://doi.org/10.3390/ environments8060051

\section{Academic Editors: Francesco}

Petracchini, Valerio Paolini, Valeria Rizza and William A. Anderson

Received: 12 April 2021

Accepted: 2 June 2021

Published: 4 June 2021

Publisher's Note: MDPI stays neutral with regard to jurisdictional claims in published maps and institutional affiliations.

Copyright: (C) 2021 by the author. Licensee MDPI, Basel, Switzerland. This article is an open access article distributed under the terms and conditions of the Creative Commons Attribution (CC BY) license (https:/ / creativecommons.org/licenses/by/ $4.0 /)$.
Department of Marine Environment and Engineering, National Sun Yat-Sen University, Kaohsiung 80424, Taiwan; p.brimblecombe@uea.ac.uk

\begin{abstract}
Visibility is a perceptible indicator of air pollution, so it is hardly surprising that it has been used to promote the regulation of air pollutants. In Hong Kong, poor visibility associated with air pollution has been linked with changes in tourist choices and health outcomes. Much research is available to examine the early deterioration of visibility in the city, and especially its relation to particulate sulfate. The period 2004-2012 saw especially poor visibility in Hong Kong and coincided with a time when pollutant levels were high. There is a reasonable correlation (multiple $r^{2}=0.57$ ) between the monthly hours of low visibility $(<8 \mathrm{~km})$ and $\mathrm{PM}_{10}, \mathrm{NO}_{2}, \mathrm{SO}_{2}$, and $\mathrm{O}_{3}$ concentrations from the late 1990s. Visibility can thus be justified as a route to perceiving air pollution. Over the last decade, visibility has improved and average pollutant concentrations have declined in Hong Kong. The changing health risk from individual pollutants parallels their concentration trends: the risk from $\mathrm{NO}_{2}$ and particulate matter at urban sites has declined, but there have been increases in the health risks from ozone as its concentrations have risen across the region, although this is dominated by concentration increases at more rural sites. Since 2004, the frequency of search terms such as visibility, air pollution, and haze on Google has decreased in line with improved visibility. Despite positive changes to Hong Kong's air quality, typically, the media representation and public perception see the situation as growing more severe, possibly because attention focuses on the air quality objectives in Hong Kong being less stringent than World Health Organisation guidelines. Policymakers increasingly need to account for the perceptions of stakeholders and acknowledge that these are not necessarily bound to measurements from monitoring networks. Improvements in air quality are hard won, but conveying the nature of such improvements to the public can be an additional struggle.
\end{abstract}

Keywords: air quality health index; public perception; health risk; stakeholders; media

\section{Introduction}

Visibility and odor are two perceptible indicators of air pollution. It is hardly surprising that these have been used in promoting the regulation of air pollutants. In times when air pollution measurements were scarce, clean air advocates such as Rollo Russell in the 1880s used visibility or fog as surrogates for measurements [1]. Declining frequency of fog from the end of the 19th century, through to improved visibility of the latter half of 20th century have been used to track air quality changes in the UK [2] and continue to offer the potential to extend records in countries where monitoring data covers a relatively short period. Similarly, in Italy, the impact of declining emissions has left its mark on visibility, while in Athens, visibility has been used as a surrogate for particulate matter back to the 1930s [3]. In northern China it has been used from the 1960s [4], where decreasing visibility has been associated with weaker winds from 1980 to 2017 [5,6] or urban activities [7]. Cleaner air and the appearance of blue skies have been an emotive issue in Chinese cities, generating wide public interest with a frequent focus on these at significant meetings, parades, and sporting events [8]. Reported frequencies of blue skies as a marker of improved air quality became associated with distrust and fabrication [9-11]. Recently 
blue skies were related to air quality improvements under COVID-19 lockdowns [12] and periods; with bushfire smoke in Sydney during December 2019 making improvements in a COVID-19 plagued year seem especially dramatic [13].

It may seem that visibility is a matter of aesthetics, yet it has been regarded as a serious issue, notable in terms of the many legal battles between the USEPA and the Sierra Club to maintain visibility in areas where air quality is higher than that required by national secondary ambient air quality standards [14,15]. Visibility came to be protected under the US Clean Air Act with the need to prevent "significant deterioration of existing air quality in any portion of any state." There have long been problems with smoke from bushfires and prescribed burns $[16,17]$, which continue to trouble many countries, such as the US, Australia, etc.

Urban areas often have tall observation decks for viewing the surrounding scenery [18], so urban visibility can have an impact on tourism. In the United Kingdom, visual amenity was used in marketing the London Eye; the world's largest observation wheel was said to offer visitors amazing views of the capital city, to a distance of $40 \mathrm{~km}$ on a clear day, but when it was hazy, visitors were disappointed [2]. In China, Beijing haze days affect the timing of tourist visits to the capital [19], though they may not respond directly to visibility issues, rather to reports of poor air quality. Nevertheless, Zhou et al. [20] were able to show tourism has a statistically significant and negative response to poor air quality $\left(\mathrm{PM}_{10}\right)$. Media, public interest groups and surveys, reveal continued public concern over air pollution, and in the previous decade - the percentage of those thinking air pollution was serious grew between 2000 and 2008. Furthermore, it was seen as more of a problem than noise waste and water pollution [21]. The level of concern among Shanghai residents, as estimated by the volume of searches on the Baidu Internet search engine, indicated there was concern about air pollution when the air quality in Shanghai or other major Chinese cities deteriorated [22]. Views about air pollution seem to be driven by external perceptions, and although there may be a mismatch between actual and perceived air pollution, where it is visible, the relationship may be stronger [23].

In Hong Kong, the issue of worsening visibility has been a key driver in demanding cleaner air pollution since the 1990s and continues to the present [24]. Air pollution became an important public health issue for Hong Kong some decades ago, stimulated by scientists such as Anthony Hedley and his research group in the 1990s (e.g., [25]), along with the public policy think tank Civic Exchange and its associated organization, the Clean Air Network (CAN). Worsening visibility became a rallying theme in the early 21st century, a concern reflected by Hong Kong's media (e.g., South China Morning Post). Sequeira and Lai [26] suggested that the scattering of light in Hong Kong is mainly related to $\mathrm{NH}_{4}$, $\mathrm{SO}_{4}$, and $\mathrm{NO}_{3}$, anions. Visibility was the subject of a study funded by the Hong Kong Environmental Protection Department (HKEPD), leading to a report [27] that reaffirmed the importance of sulfate as a control on visibility. In the Pearl River Delta, low visibility events typically occur during periods of high particulate loading, commonly accompanied by specific meteorological conditions such as high humidity [28,29]. Concerns over visibility in relation to health [30] and energy as a driver [24] have maintained its importance as an issue. More recently, there have been worries about the potential effect on tourism through dissatisfaction with visibility in the city [31]. Yue et al. [32] examined the perceptions of visibility degradation in Hong Kong and showed that both residents and visitors linked it to environmental issues.

This paper looks at the relationship between visibility and air pollution, but it is mostly concerned with the effects these have on health, public perception, and policy. It will not treat the relationship between the aerosol composition and visible range, but will consider a loose relationship between air pollution and perceptions of visibility. Thus, advocacy groups argue that the dangers of air pollutants may be concealed because threats may be invisible; such groups will often use visibility as an indicator of air quality. This study takes a particular interest in how the relationships between air pollution, visibility, and health risk change over time, with a particular focus on the improvement in visibility in Hong 
Kong since 2004. It additionally considers the impact visibility has on public perception of pollution in the region. Many publications have looked mostly at visibility in Hong Kong over the period when it deteriorated $[20,33]$. Even relatively recent papers $[24,31,32]$ have limited their attention to the part of the record when visibility was still in decline (up to $\sim 2010$ ), so the aim here is to examine the record through to 2020 and include a period of improvement.

\section{Materials and Methods}

Long-term records of visibility in Hong Kong are available from the Hong Kong Observatory (HKO). The lengthier records from 1968 present the number of hours of reduced visibility observed at the HKO. Reduced visibility means that the visual range falls below $8 \mathrm{~km}$, with relative humidity $<95 \%$ and no fog, mist, or precipitation. The values at the Observatory on the Kowloon Peninsular are based on hourly observations made by trained meteorological observers. There are further observations derived from automatic visibility readings made at Chek Lap Kok, Central, Sai Wan Ho, and Waglan Island (see map Figure 1), representing a 10-minute interval ending at the indicated time. The long-term record as monthly values is available at: https:/ /www.hko.gov.hk/en/cis/ statistic/hko_redvis_statistic.htm (accessed 3 June 2021), along with the records at Hong Kong International Airport since 1997 at: https:/ / www.hko.gov.hk/en/cis/statistic/hka_ redvis_statistic.htm (accessed 3 June 2021).

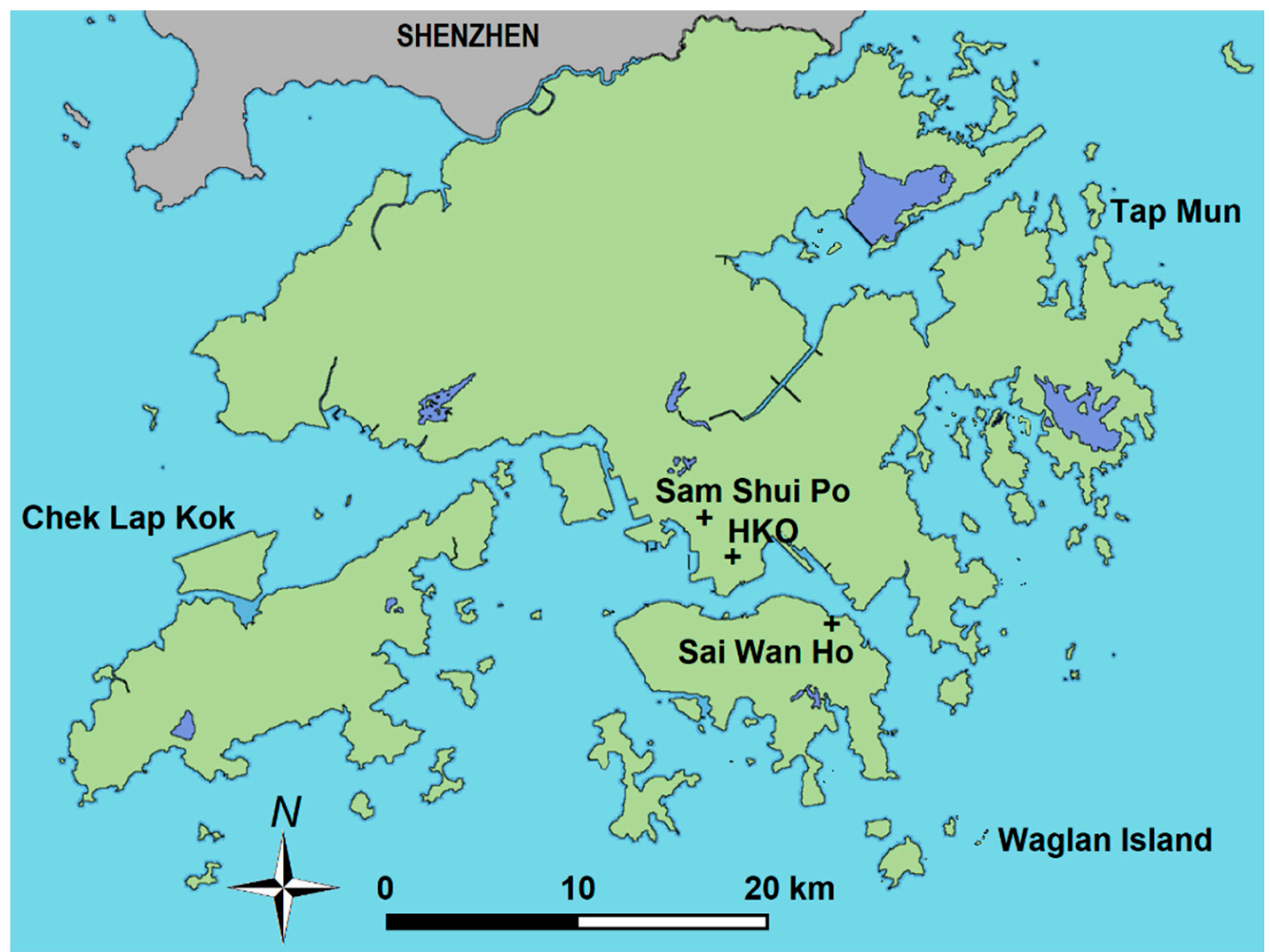

Figure 1. Map of Hong Kong showing locations mentioned in the text. Mong Kok, although not displayed, lies midway between HKO and Sam Shui Po.

Air pollutant concentrations are available from the HKEPD monitoring network, which consists of 14 general stations, three roadside stations, and a rural station, which represents regional background. Many sites have records that begin in the 1990s (available at https://cd.epic.epd.gov.hk/EPICDI/air/station/?lang=en and last accessed 3 June 2021). The stations provide hourly measurements of $\mathrm{NO}_{2}, \mathrm{NOx}, \mathrm{CO}, \mathrm{O}_{3}, \mathrm{PM}_{2.5}$, and $\mathrm{PM}_{10}$, although $\mathrm{CO}$ measurements are not available for all the stations, being more typically available for roadside sites. In this study, the record from the Sam Shui Po (SSP) urban 
site has been used most frequently. Average air quality trends in Hong Kong are also well documented [34].

Google trends (https: / / trends.google.com/117 and accessed 3 June 2021) provides an indication of the changing use of search terms over time and allows the search volume of different queries over time to be explored. The data has been used in a variety of projects, such as searching for movements in the stock market [35] or to public views of political issues [36].

The risk of daily hospital admissions imposed by pollutants in Hong Kong is embodied in its Air Quality Health Index (AQHI). The index was introduced in late 2013 and adopts a commonly used scale with eleven points 1 to 10 and 10+ [37]. The scale is seemingly reversed as it expresses a kind of risk rather than air quality per se, because a low AQHI represents a situation where air quality is high. The AQHI of the current hour is calculated from the sum of the percentage added health risk $\left(R_{\mathrm{AHR}}\right)$ of daily hospital admissions attributable to the 3 hour moving average concentrations of $\mathrm{NO}_{2}, \mathrm{SO}_{2}, \mathrm{O}_{3}$, and particulate matter. The latter is taken as respirable suspended particulate (RSP or $\mathrm{PM}_{10}$ ) or fine suspended particulate matter (FSP or $\left.\mathrm{PM}_{2.5}\right)$, whichever poses a higher health risk. The $R_{\mathrm{AHR}}$ of each pollutant depends on its concentration and a risk factor derived from local health statistics and air pollution data. The summation and equations are as follows:

$$
R_{\mathrm{AHR}}=R_{\mathrm{AHR}, \mathrm{NO} 2}+R_{\mathrm{AHR}, \mathrm{SO} 2}+R_{\mathrm{AHR}, \mathrm{O} 3}+R_{\mathrm{AHR}, \mathrm{PM}}
$$

where $R_{\mathrm{AHR}, \mathrm{PM}}$ is $R_{\mathrm{AHR}, \mathrm{PM} 10}$ or $R_{\mathrm{AHR}, \mathrm{PM} 2.5}$, whichever is higher

The parameter $R_{\mathrm{AHR}, \mathrm{i}}$ is the added health risk of pollutant $\mathrm{i}$ determined as $R_{\mathrm{AHR}, \mathrm{i}}=$ $100\left(\exp \left(\beta_{\mathrm{i}} c_{\mathrm{i}}\right)-1\right)$ and $c_{\mathrm{i}}$ the 3 hour moving average concentration of pollutants $\left(\mu \mathrm{g} \mathrm{m} \mathrm{m}^{-3}\right)$ with the factors: $\beta_{\mathrm{NO} 2}=0.0004462559 ; \beta_{\mathrm{SO} 2}=0.0001393235 ; \beta_{\mathrm{O} 3}=0.0005116328$; $\beta_{\mathrm{PM} 10}=0.0002821751$, and $\beta_{\mathrm{PM} 2.5}=0.0002180567$ [38].

Data analysis in the study used simple UNIX scripts, while statistical calculations took advantage of a number of online tools. Wessa Net was used for multiple regression. The nonparametric Theil-Sen slope used the single case research calculator: (http:/ / www. singlecaseresearch.org/calculators / theil-sen, last accessed 3 June 2021).

\section{Results and Discussion}

The classic picture of visibility in Hong Kong is shown in the graphical abstract. This is frequently seen in popular presentations and academic publications and is a feature of the $\mathrm{HKO}$ website. It conveys a sense of change occurring over more than fifty years. In the past, this record has been used to convey the worsening visibility in the city up to the first decade of the 21st and in parallel, represent the trend in long-term particulate levels given the lack of long-term measurements. The visibility record shown in Figure 2a gives the hours of low visibility $\left(n_{\mathrm{LV}}\right)$ each month as a function of time, with a line representing the smoothed annual running mean. The visibility at the airport is shown in Figure $2 b$, and although it initially has more hours of low visibility, it improves rapidly and continuously from peaks early in the 21st century, showing a rather similar change over time to that at the HKO, suggesting that these changes were widely experienced across the territory. The figure indicates the situation of worsening visibility that created so much concern 10-20 years ago. However, from about 2005, the number of hours of low visibility gradually decreased and loosely aligned with improvements in $\mathrm{PM}, \mathrm{NO}_{2}, \mathrm{SO}_{2}$, though not $\mathrm{O}_{3}$ (Figure $2 \mathrm{c}-\mathrm{f}$ ). The years 2004-2006 contained seven of the worst months in the Hong Kong record. The other five worst months were in February, March, July, August and November, between 2010 and 2012.

The early decades of worsening visibility led early to it becoming an icon for Hong Kong's poor air quality. Even today, deteriorating visibility seems to be retained as accepted truth and can still found in some quite recent publications $[24,31,32]$ or presentations that have not been updated. The preoccupation with worsening visibility is understandable given the changes that have affected environmental quality in the region. The industrialization has been so rapid that "deterioration in air quality and visibility have become quite 
prominent and the PRD (Pearl River Delta) region is one of China's four top regions for severe haze" [39]. There has been continuing concern that evident haze is a strong reminder of the city's poor air quality, which might limit its ability to attract tourists, professional workers, and investment. Concern about visibility deterioration is also supported by articles in the South China Morning Post, which has advocated strongly for improved air quality in Hong Kong.

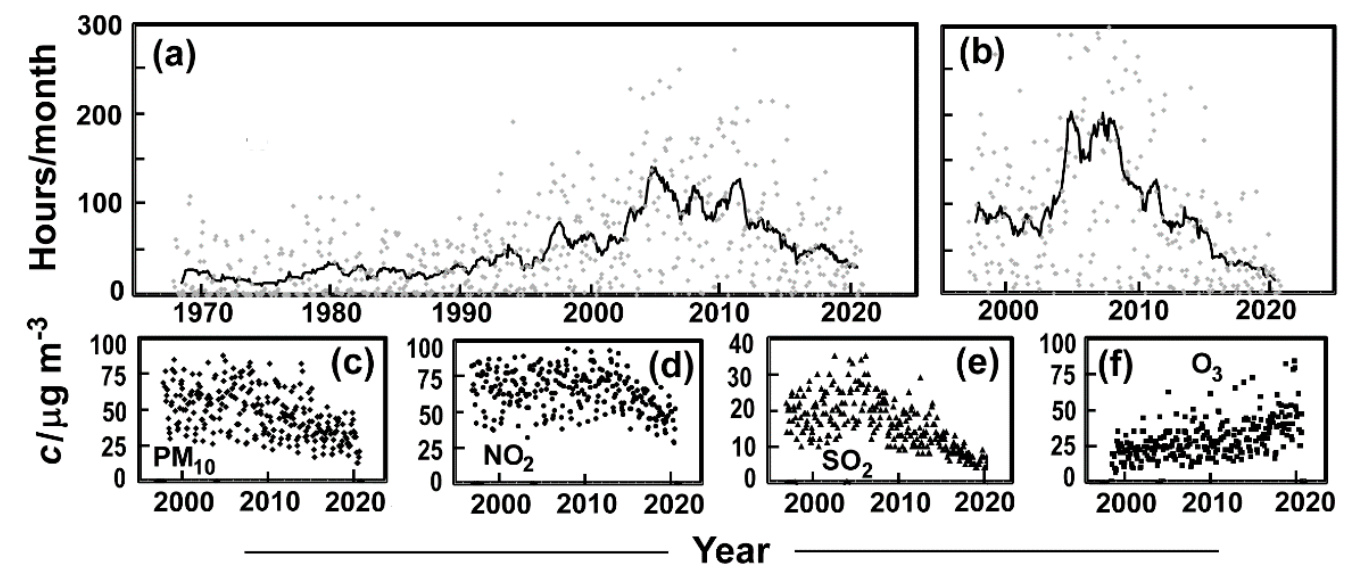

Figure 2. (a) Hours of low visibility each month $\left(n_{\mathrm{LV}}\right)$ at $\mathrm{HKO}$ and (b) Hong Kong International Airport, along with the change in monthly average air pollutant concentrations at Sam Shui Po for (c) $\mathrm{PM}_{10}$, (d) $\mathrm{NO}_{2}$, (e) $\mathrm{SO}_{2}$, and (f) $\mathrm{O}_{3}$.

At times there seems to be a reluctance to acknowledge improvements in visibility in Hong Kong. However, this has been noted in some more recent publications: "Shenzhen has experienced increased air pollution, reflected in the frequency of haze events. The worst period was in 2004, during which there were 187 days with haze events" [40]. Part of the reluctance to accept improved visibility may be that it is strongly coupled to air pollution, so drawing attention to improved visibility might suggest, in parallel, that air quality had improved in the city. The air pollution problem is generally perceived as growing more severe by the media and the public [41], and where improvements are acknowledged, they are often framed in the negative sense, e.g., that improvements have not continued [42]. Additionally, it has been argued the public are not able to sense gradual improvements in air quality and are more influenced by heavily polluted days $[43,44]$.

\subsection{Visibility and Pollution}

The relationship between visibility and pollutant load was detailed in the Study of Visibility Reduction and its Causes in Hong Kong [27]. This relationship is complex, especially at short-time resolution and best involves considering the ions in the particulate material. However, the work presented here focuses on the more general relationship between visibility and monitored air pollutants. The changes in monthly average concentrations of the four pollutants $\mathrm{PM}_{10}, \mathrm{NO}_{2}, \mathrm{SO}_{2}$, and $\mathrm{O}_{3}$ at the SSP general urban site a few kilometers distant from the $\mathrm{HKO}$ are plotted in Figure $2 \mathrm{c}-\mathrm{e}$. It would have been preferable to use $\mathrm{PM}_{2.5}$, but the record did not become available until 2011. Other sites might have been chosen to represent the $\mathrm{HKO}$, but as the visual range integrates pollution over long path lengths, it is hard to decide the most appropriate ground-level monitoring site. However, it is evident from the data that there is a general decrease in average concentrations of $\mathrm{PM}_{10}, \mathrm{NO}_{2}, \mathrm{SO}_{2}$, and $\mathrm{O}_{3}$ increases across a period when visibility is improving. The changes in $\mathrm{O}_{3}$ may result from a decreased titration by NO. It is also possible that higher $\mathrm{O}_{3}$ concentrations lead to higher concentrations of secondary particulate matter in Hong Kong, where (i) a large proportion (25-45\%) of sulfate is of secondary origin [45] and (ii) in wintertime, secondary organic carbon (as carbon) makes up slightly more of the aerosol than the sulfate, while in summer, it is about a half [46]. Particulate concentrations of 
species likely to control visibility are not typically provided to the public on a regular basis in Hong Kong. However, multiple linear regression reveals a satisfying relationship between monthly hours of low visibility $\left(n_{\mathrm{LV}}\right)$ and the gaseous pollutant concentrations $(\mathrm{c})$, with Equation (2) suggesting:

$$
n_{\mathrm{LV}}=+1.5 c_{\mathrm{NO} 2}+0.3 c_{\mathrm{O} 3}+1.5 c_{\mathrm{PM} 10}+0.63 c_{\mathrm{SO} 2}-109
$$

with $r^{2}(0.57)$, so the equation explains a reasonable amount of the variance. However, the individual $p_{2}$ values for both $c_{\mathrm{SO} 2}$ and $c_{\mathrm{O} 3}$ suggest little significance, i.e., 0.14 and 0.18 . The other parameters are all significant $\left(p_{2}<0.0001\right)$. Pollutant gases are hardly a driver of visibility, but the relationship supports the view that pollution, as measured by the HKEPD network and visibility are related, a link, likely indirect, that aligns with public expectation (see also [9]) and health. Thus, we can perceive air pollution through its surrogate visibility, as long $\mathrm{RH}<95 \%$ and there is no low cloud, to avoid confusion with mist. Sequeira and Lai [26], and later Wang [27], pointed out that visibility in Hong Kong seems primarily a sulfate-driven process. Sulfur dioxide has long been in decline in Hong Kong as a result of legislation which meant there were sharp reductions in $\mathrm{SO}_{2}(80 \%)$ and sulfate particles $(41 \%)$ in the early 1990s [47,48].

Given the relationship between markers of air pollution and visibility, it seems natural to argue that improved visibility in Hong Kong reflects a general improvement in its air quality. However, such improvements are not well accepted and do not align with the representation of pollution in the media or opinion surveys [41]. It could be argued that although the pollutant load decreased in line with improving visibility, health effects did not. As different pollutants have different health outcomes, these might not improve even though some pollutant concentrations declined. Nevertheless, earlier studies (e.g., [30]) promoted the idea of a relationship between visibility and health in Hong Kong.

\subsection{Pollutants and the Health Index}

The tensions noted in the previous paragraph mean it is worth exploring the way that key air pollutants and health risk have changed over time. In Hong Kong, power stations have long been an important source of air pollutants, but they have improved, such that shipping has become a more dominant source, especially for $\mathrm{SO}_{2}$. Road transport is relevant to $\mathrm{NO}_{2}$, and the volatile organic emissions and carbon monoxide contribute as precursors in the production of $\mathrm{O}_{3}$. Many studies in the past have explored the notion that air pollution, visibility, and health are interconnected [49-51], though here, this relation is explored in terms of perceptions in Hong Kong and its special health index. The AQHI is only available from December 2013, but the method can be applied using earlier measurements, although there are difficulties, most notably, the absence of $\mathrm{PM}_{2.5}$. In the calculations here, where $\mathrm{PM}_{2.5}$ is not available, $\mathrm{PM}_{10}$ is used, and while this leads to error, $\mathrm{PM}_{10}$ and $\mathrm{PM}_{2.5}$ tend to be well correlated $\left(r^{2} \sim 0.88\right)$, so it is not as serious as one might first imagine.

The added health risk calculated for each pollutant is plotted additively in Figure $3 \mathrm{a}$ and gives a sense of the strong seasonal variation, with the total risk almost doubling from summer to winter. However, the overall risk seems to have declined. Across the record, since 1998 the dominant risk derives from $\mathrm{NO}_{2}$ (about half) as illustrated by the large shaded-area for $\mathrm{NO}_{2}$ in Figure $3 \mathrm{a}$. Figure $3 \mathrm{~b}$ shows the monthly proportions during the years 2015-2019. Little risk is associated with $\mathrm{SO}_{2}$, so the changing balance can be largely attributed to $\mathrm{PM}, \mathrm{NO}_{2}$, and $\mathrm{O}_{3}$ as represented in the ternary plot (Figure 3c), illustrating that over time the risk has come to be dominated by ozone; now at $\sim 38 \%$.

The general site at SSP cannot properly represent risk throughout Hong Kong, so it is worth examining roadside and rural values. This is not to say they represent exposures of any individual person, but reminds us of differences that arise, especially because of the heterogeneity of pollutants in urban areas. Figure $3 \mathrm{~d}$ shows calculated risk at the roadside using the Mong Kok site on busy Nathan Road, at its junction with Lai Chi Kok Road, $\sim 1.5 \mathrm{~km}$ from the HKO. Since 1996, high concentrations of $\mathrm{NO}_{2}$ make it a large and dominant contributor to risk. However, much as expected, this declines in line with 
decreases in $\mathrm{NO}_{2}$ at Hong Kong roadside sites, despite increases in the ratio: $\mathrm{NO}_{2} / \mathrm{NO}$ in emissions [52]. Particulate matter has also decreased over time at roadside sites. There are slight increases in the risk imposed by ozone, though the record is short (Figure 3d).

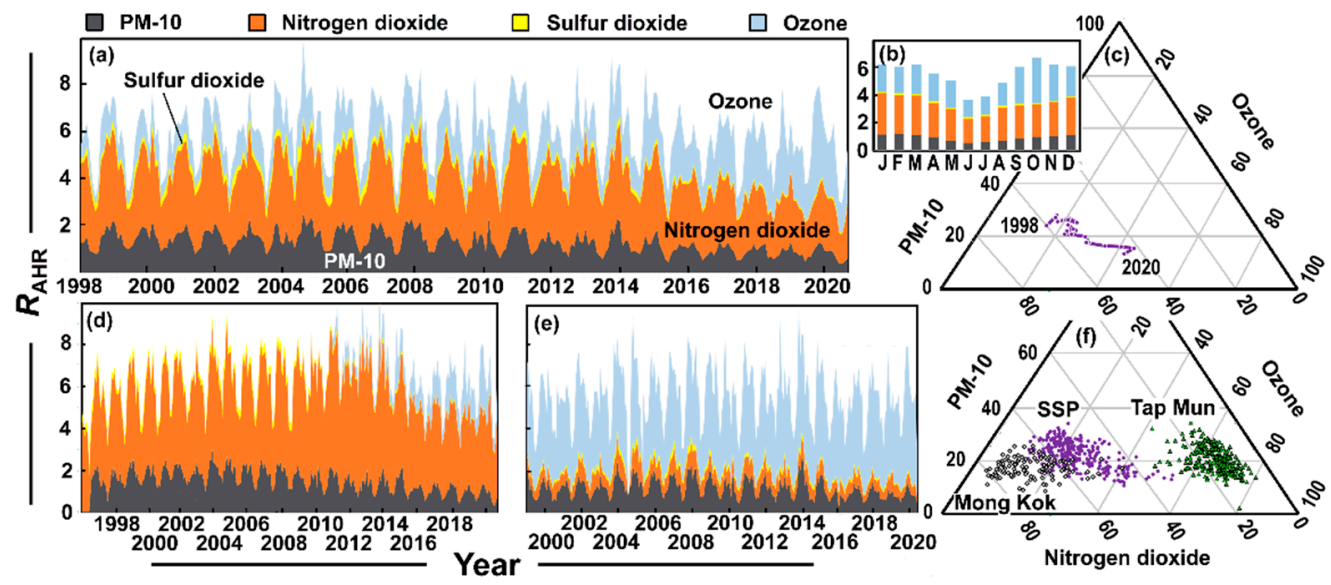

Figure 3. (a) Added contributions to the health risk $\left(R_{\mathrm{AHR}}\right)$ from $\mathrm{PM}_{10}, \mathrm{NO}_{2}, \mathrm{SO}_{2}$, and $\mathrm{O}_{3}$ at Sam Shui Po, (colloquially SSP). (b) Monthly averages of health risk for the pollutants for the years 2015-2019. (c) Ternary diagram showing average annual health risk from $\mathrm{PM}_{10}, \mathrm{NO}_{2}$, and $\mathrm{O}_{3}$ at Sam Shui Po from 1998-2020. (d) Added contributions to the health risk from $\mathrm{PM}_{10}, \mathrm{NO}_{2}, \mathrm{SO}_{2}$, and $\mathrm{O}_{3}$ at the Mong Kok roadside site. (e) Added contributions to the health risk from $\mathrm{PM}_{10}, \mathrm{NO}_{2}, \mathrm{SO}_{2}$, and $\mathrm{O}_{3}$ at the rural site on Tap Mun (Grass Island). (f) Ternary diagram showing average monthly health risk from $\mathrm{PM}_{10}, \mathrm{NO}_{2}$, and $\mathrm{O}_{3}$ at Sam Shui Po (1998-02/2020-09), Mong Kok (2011-01/2020-09), and Tap Mun (1998-01/2020-04). Note: (i) scale change between Figure 3a,d,e (ii) color/shades and order for the pollutants plotted remain the same for Figure $3 \mathrm{a}, \mathrm{b}, \mathrm{d}, \mathrm{e}$.

The heterogeneity of the potential health threat can be further explored at the remote rural site of Tap Mun (or Grass Island). The rural record represents a situation largely free from nearby sources of primary pollutants, but the total health risk is not notably smaller than the roadside site (Figure $3 e$ ) and is dominated by $\mathrm{O}_{3}$, with $\mathrm{NO}_{2}$ making little contribution. There are subtle decreases in the potential health impact of $\mathrm{NO}_{2}, \mathrm{SO}_{2}$, and particulate matter at Tap Mun. The risk associated with $\mathrm{O}_{3}$ is dominant and increases slightly over time, the Theil-Sen slope suggesting an annual decline in risk $R_{\mathrm{AHR}, \mathrm{O} 3}$ of $\sim 0.017$. This aligns with rural $\mathrm{NO}_{2}, \mathrm{SO}_{2}$, and particulate matter concentrations being low, while $\mathrm{O}_{3}$ has been about $70 \mu \mathrm{g} \mathrm{m}^{-3}$ during the first decades of the century.

The relative health risks imposed by the pollutants at the three sites are shown in the ternary diagram (Figure 3f). They acquire risk from different pollutants, so hint at the range of risk exposures experienced by Hong Kong residents. Some who live close to busy roads may be best represented by a risk accumulating as indicated for Mong Kok, while those in rural areas or the islands may be more akin to the balance of risk suggested by Tap Mun. The remote site could also represent the exposures of those who live in high-rise apartments far above roads. It is important to note that in Hong Kong, more than half the population lives above Floor No. 15; in that sense, it is the tallest city in the world. High $\mathrm{O}_{3}$ at more remote locations means that there is surprisingly little difference between the risk in rural and urban areas. Overall, the health risk shows strong seasonal variation and gradual improvement in the threat from primary pollutant risk, while that from $\mathrm{O}_{3}$ is increasing as an issue of considerable concern in Hong Kong [53].

\subsection{Perception of Visibility and Air Quality}

The general picture of trends in air quality suggests improvement and a slight decrease in risk to many Hong Kong residents, living as they do in urban areas. In parallel, visibility has improved, yet such changes come at a time of increased public anxiety about air pollutants. This concern is portrayed in the media and through publications of CAN, often 
drawing attention to episodes or that Hong Kong's air quality objectives are not as stringent as the guidelines recommended by the World Health Organisation.

A trend in public opinion about air quality in Hong Kong can be seen from Google Trends, which provides the frequency of search queries in Google over time (Figure 4). The record goes back to 2004 and is displayed for the search terms (i) "visibility", (ii) "air pollution", and (iii) "haze". Search frequencies roughly parallel the smoothed decline in hours of low visibility. Search frequency appears noisy because sometimes the number of searches is low, so there are frequent zero values. Caution is needed when interpreting these changes. Although they show a declining interest in searching, this does not necessarily reflect a decline in concern, as it could be that public knowledge has reached a point where searches are no longer frequent.

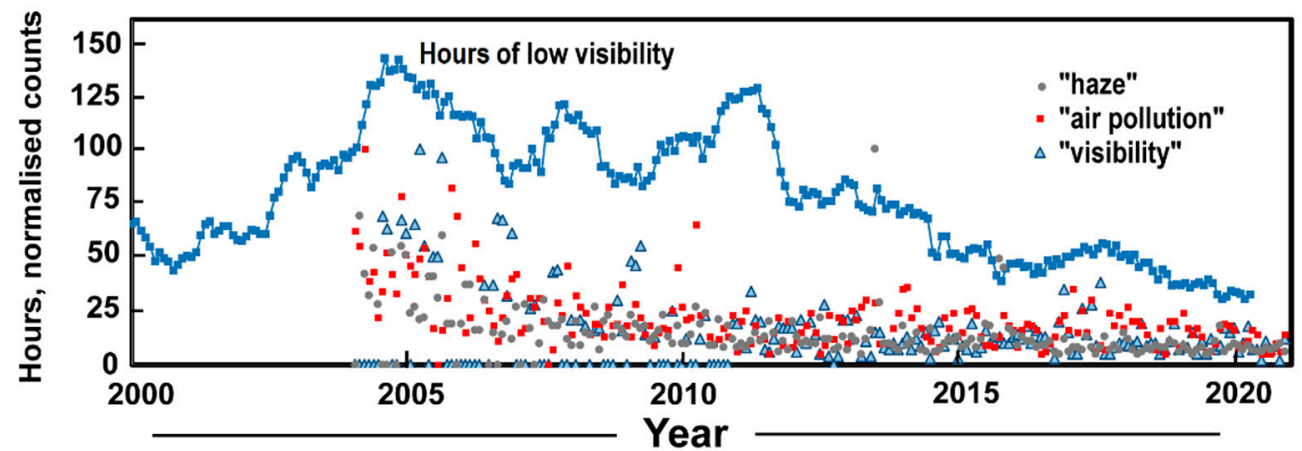

Figure 4. Hours of low visibility each month at the HKO as the annual running mean, and the frequency of search queries from Hong Kong in Google Trends 2004-2020 for "visibility", "air pollution", and "haze".

Perceptions of the relationship between visibility and air pollution may also be sensed in images chosen by the media. Hong Kong's English language newspaper, the South China Morning Post published 70 articles on air pollution from December 2018 to December 2020 to hint at current perceptions. Forty of these contained images showing visibility degraded by haze, suggesting that haze remains an important icon for air pollution. Haze was more frequently associated with air pollution than other images, such as traffic or factories chimneys with plumes of smoke. Figure 5 shows the key representations in the pictures featured in articles, e.g., haze surgical mask, plumes from a chimney, blue or clear sky notions from images associated with these articles.

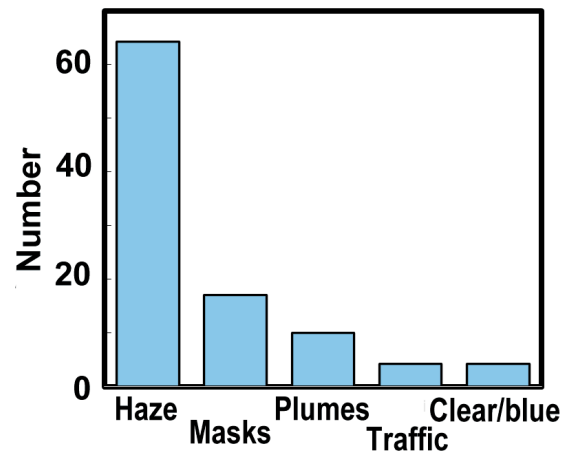

Figure 5. The number of representations of haze, surgical masks, plumes from a chimney and blue or clear skies from pictures in 70 articles about air pollution published in the South China Morning Post December 2018 to December 2020.

Air quality and visibility in Hong Kong since the earliest measurements, but neither are yet satisfactory-taking average $\mathrm{PM}_{2.5}$ as $\sim 20 \mu \mathrm{g} \mathrm{m}^{-3}$ ranks the city 43rd worst among national capitals [54]. Among European capitals, only Sarajevo, Skopje, Sofia, Pristina, 
Belgrade, and Athens were worse. The general improvements in Hong Kong, while framed by the HKEPD in terms of its air quality objectives [55], receive little public comment. Stakeholders remain concerned that these objectives are less stringent than WHO guidelines [56] or that there are continued exceedance for $\mathrm{NO}_{2}$ at general and roadside stations and ozone breaches the standard at general sites [57]. Concentrations of air pollutants are at times undesirably high, yet the annual concentrations of primary air pollutants have decreased over the years. The smoothed health impact of these pollutants, as illustrated in Figure 3, also suggests a declining health risk, although there is a substantial seasonal variation. Although the threat from particulate matter and $\mathrm{NO}_{2}$ has decreased over the last decade, the risk from $\mathrm{O}_{3}$ has grown, justifying the concerns expressed by CAN [40].

Despite improved visibility in Hong Kong, it remains an icon for poor air quality in the media. It is also possible to discern a decreased frequency of searches for visibility, air pollution, and haze on Google, though the meaning of those declines is open to a range of explanations. Lower air pollutant concentrations and better visibility are in contrast with a public perception that conditions in the city have become poorer. The CAN [41] Survey on Air Quality and Respiratory Health of Children suggests that of the 512 respondents, more than half believed that air quality had become worse over the previous three years. Sometimes positive public visions of change can be apparent with quite modest or localized improvements in air pollution, e.g., changes during road blockages during the 2014 Umbrella Movement [58], which drew comments long afterwards [59]. In 2020, the public readily accepted improvements to air pollution during COVID-19 lockdowns, though it was hard to assess whether views derived from personal observations, media promotion, vivid imagery, or desire to see something positive a time of crisis [13]. Reasons for our perceptions can be hard to ascertain, but as Bickerstaff and Walker [60] pointed out, monitoring data does not drive public opinion as much as localized social perceptions.

\section{Conclusions}

Poor visibility in Hong Kong has often been linked to air pollution and its health impact, particularly in a period when visibility was in decline. As the primary pollutants have decreased in concentration in recent years, visibility has improved. However, ozone has been increasing, and while this poses an increasing risk to health, a secondary pollutant is likely to have little direct effect on visibility. Exposure to ozone may be especially relevant to those living away from busy streets in high-rise apartments or in rural areas where intuitively, one might believe risks from air pollution to be lower. Increasing concentrations of ozone weakens the direct link between visibility and the health risk imposed by air pollution. Despite some general improvements in air quality, these are not necessarily reflected in the public or media views about air pollution, and visibility or haze remains an important icon for air pollution in Hong Kong. The air quality problem is seen as one that is becoming ever more severe. Policymakers need to account for the air quality perceptions of stakeholders and acknowledge that these are not necessarily bound to concentration measurements from a monitoring network. Improvements in air quality are hard-won, but conveying the nature of improvements to the public can be a continuing struggle.

Funding: This research received no external funding.

Institutional Review Board Statement: Not applicable.

Informed Consent Statement: Not applicable.

Data Availability Statement: Data is publicly available as denoted by URLs.

Acknowledgments: Visibility in Hong Kong has been a popular discussion topic with my students over a number of years and I learned much from these discussions, especially an undergraduate dissertation: Politics of Visibility.

Conflicts of Interest: The author declares no conflict of interest. 


\section{References}

1. $\quad$ Brimblecombe, P. The Big Smoke; Methuen: London, UK, 1987.

2. Doyle, M.; Dorling, S. Visibility trends in the UK 1950-1997. Atmos. Environ. 2002, 36, 3161-3172. [CrossRef]

3. Founda, D.; Kazadzis, S.; Mihalopoulos, N.; Gerasopoulos, E.; Lianou, M.; Raptis, P.I. Long-term visibility variation in Athens (1931-2013): A proxy for local and regional atmospheric aerosol loads. Atmos. Chem. Phys. 2016, 16, 11219. [CrossRef]

4. Chen, H.; Wang, H. Haze days in North China and the associated atmospheric circulations based on daily visibility data from 1960 to 2012. J. Geophys. Res. Atmos. 2015, 120, 5895-5909. [CrossRef]

5. Deng, J.; Du, K.; Wang, K.; Yuan, C.S.; Zhao, J. Long-term atmospheric visibility trend in Southeast China, 1973-2010. Atmos. Environ. 2012, 59, 11-21. [CrossRef]

6. Zhang, Y.; Gao, L.; Cao, L.; Yan, Z.; Wu, Y. Decreasing atmospheric visibility associated with weakening winds from 1980 to 2017 over China. Atmos. Environ. 2020, 224, 117314. [CrossRef]

7. Fu, W.; Chen, Z.; Zhu, Z.; Liu, Q.; Qi, J.; Dang, E.; Wang, M.; Dong, J. Long-term atmospheric visibility trends and characteristics of 31 provincial capital cities in China during 1957-2016. Atmosphere 2018, 9, 318. [CrossRef]

8. Fu, S.; Ma, Z.; Peng, J. "Political blue sky" in fog and haze governance: Evidence from the local major international events in China. Environ. Sci. Pollut. Res. 2020, 28, 775-788. [CrossRef] [PubMed]

9. Brimblecombe, P.; Zong, H. Citizen perception of APEC blue and air pollution management. Atmos. Environ. 2019, 214, 116853. [CrossRef]

10. Ghanem, D.; Zhang, J. Effortless Perfection: Do Chinese cities manipulate air pollution data? J. Environ. Econ. Manag. 2014, 68, 203-225. [CrossRef]

11. Shen, Y.; Ahlers, A.L. Blue sky fabrication in China: Science-policy integration in air pollution regulation campaigns for mega-events. Environ. Sci. Policy 2019, 94, 135-142. [CrossRef]

12. Kotnala, G.; Mandal, T.K.; Sharma, S.K.; Kotnala, R.K. Emergence of Blue Sky over Delhi Due to Coronavirus Disease (COVID-19) Lockdown Implications. Aerosol Sci. Eng. 2020, 4, 228-238. [CrossRef]

13. Brimblecombe, P.; Lai, Y. Subtle Changes or Dramatic Perceptions of Air Pollution in Sydney during COVID-19. Environments 2021, 8, 2. [CrossRef]

14. Disselhorst, T.M. Sierra Club v. Ruckelshaus: On a Clear Day ... . Ecol. Law Q. 1974, 4, 739.

15. Ostrov, J. Visibility protection under the Clean Air Act: Preserving scenic and parkland areas in the Southwest. Ecol. Law Q. 1982, 10, 397.

16. Packham, D.R.; Vines, R.G. Properties of bushfire smoke: The reduction in visibility resulting from prescribed fires in forests. $J$. Air Pollut. Control Assoc. 1978, 28, 790-795. [CrossRef]

17. Ravi, V.; Vaughan, J.K.; Wolcott, M.P.; Lamb, B.K. Impacts of prescribed fires and benefits from their reduction for air quality, health, and visibility in the Pacific Northwest of the United States. J. Air Waste Manag. Assoc. 2019, 69, 289-304. [CrossRef] [PubMed]

18. Hyslop, N.P. Impaired visibility: The air pollution people see. Atmos. Environ. 2009, 43, 182-195. [CrossRef]

19. Zhang, A.; Zhong, L.; Xu, Y.; Wang, H.; Dang, L. Tourists' perception of haze pollution and the potential impacts on travel: Reshaping the features of tourism seasonality in Beijing, China. Sustainability 2015, 7, 2397-2414. [CrossRef]

20. Zhou, X.; Santana Jiménez, Y.; Pérez Rodríguez, J.V.; Hernández, J.M. Air pollution and tourism demand: A case study of Beijing, China. Int. J. Tour. Res. 2019, 21, 747-757. [CrossRef]

21. Wong, T.K.Y.; Wan, S.P. Environmental awareness and behavior in Hong Kong: A decade of development. In Proceedings of the TASPAA Partnership with the International Conference on Sustainable Development, Taichung City, Taiwan, 24 May 2008.

22. Dong, D.; Xu, X.; Xu, W.; Xie, J. The Relationship between the Actual Level of Air Pollution and Residents' Concern about Air Pollution: Evidence from Shanghai, China. Int. J. Environ. Res. Public Health 2019, 16, 4784. [CrossRef]

23. Peng, M.; Zhang, H.; Evans, R.D.; Zhong, X.; Yang, K. Actual air pollution, environmental transparency, and the perception of air pollution in China. J. Environ. Dev. 2019, 28, 78-105. [CrossRef]

24. To, W.M.; Lee, P.K. Energy consumption and economic development in Hong Kong, China. Energies 2017, 10, 1883. [CrossRef]

25. Ong, S.G.; Liu, J.; Wong, C.M.; Lam, T.H.; Tam, A.Y.C.; Daniel, L.; Hedley, A.J. Studies on the respiratory health of primary school children in urban communities of Hong Kong. Sci. Total Environ. 1991, 106, 121-135. [CrossRef]

26. Sequeira, R.; Lai, K.H. The effect of meteorological parameters and aerosol constituents on visibility in urban Hong Kong. Atmos. Environ. 1998, 32, 2865-2871. [CrossRef]

27. Wang, T. Study of Visibility Reduction and Its Causes in Hong Kong, Report to the Air Services Group; Tender Ref. AS 01-286; The Environmental Protection Department of HKSAR: Kowloon, Hong Kong, 2003.

28. Chen, H.H.; Wu, D.; Tan, H.B.; Li, F.; Fan, S.J. Study on the character of haze weather process from the year 2001 to 2008 over the Pearl River Delta. J. Trop. Meteorol. 2010, 26, 147-155.

29. Deng, H.; Tan, H.; Li, F.; Cai, M.; Chan, P.W.; Xu, H.; Huang, X.; Wu, D. Impact of relative humidity on visibility degradation during a haze event: A case study. Sci. Total Environ. 2016, 569, 1149-1158. [CrossRef]

30. Thach, T.Q.; Wong, C.M.; Chan, K.P.; Chau, Y.K.; Chung, Y.N.; Ou, C.Q.; Yang, L.; Hedley, A.J. Daily visibility and mortality: Assessment of health benefits from improved visibility in Hong Kong. Environ. Res. 2010, 110, 617-623. [CrossRef] [PubMed]

31. Yue, R.P.; Lee, H.F.; Hart, M.A. The human dimension of visibility degradation in a compact city. Nat. Hazards 2016, 82, 1683-1702. [CrossRef] 
32. Yue, R.P.; Lee, H.F.; Hart, M.A. Perceptions of visibility degradation in Hong Kong. J. Environ. Plan. Manag. 2017, 60, 1073-1091. [CrossRef]

33. Chan, C.K.; Yao, X. Air pollution in mega cities in China. Atmos. Environ. 2008, 42, 1-42. [CrossRef]

34. HKEPD. Pollutant Long-Term Trends (1990-2018). 2019. Available online: https://www.aqhi.gov.hk/api_history/english/ report/files/aqt18e.pdf (accessed on 3 June 2021).

35. Ball, P. Counting Google searches predicts market movements. Nature 2013, 12879. [CrossRef]

36. Corbi, R.; Picchetti, P. The cost of gendered attitudes on a female candidate: Evidence from Google Trends. Econ. Lett. 2020, 196, 109495. [CrossRef]

37. GovHK. Air Quality Health Index. Hong Kong Special Administrative Region Government, 2014. Available online: http: / /www.gov.hk/en/residents/environment/air/aqhi.htm (accessed on 3 June 2021).

38. Wong, T.W.; Tam, W.W.S.; Lau, A.K.H.; Ng, S.K.W.; Yu, I.T.S.; Wong, A.H.S.; Yeung, D. A Study of the Air Pollution Index Reporting System, Report to the Air Services Group; Tender Ref. AP 07-085; The Environmental Protection Department of HKSAR: Kowloon, Hong Kong, 2012.

39. Tan, H.B.; Yin, Y.; Li, F.; Liu, X.T.; Chan, P.W.; Deng, T.; Deng, X.J.; Wan, Q.L.; Wu, D. Measurements of particle number size distributions and new particle formation events during winter in the Pearl River Delta region, CHINA. J. Trop. Meteorol. 2016, 22, 191.

40. Yang, H.-L.; Zhang, Y.; Li, L.; Chan, P.W.; Lu, C.; Zhang, L. Characteristics of Aerosol Pollution under Different Visibility Conditions in Winter in a Coastal Mega-City in China. J. Trop. Meteorol. 2020, 26. [CrossRef]

41. CAN. Survey on Air Quality and Respiratory Health of Children. 2020. Available online: http://www.hongkongcan.org/doclib/ Parentsurveyppt.pdf (accessed on 10 January 2021).

42. CAN. Deterioration of Air Quality in PRD Region as Ozone Level Continues to Break Record High and Level of Nitrogen Dioxide and Particulate Matters Cease to Drop. 2020. Available online: http://www.hongkongcan.org/hk/article/deteriorationairquality-prd-region/ (accessed on 3 June 2021).

43. Li, X.; Qiao, Y.; Zhu, J.; Shi, L.; Wang, Y. The "APEC blue" endeavor: Causal effects of air pollution regulation on air quality in China. J. Clean. Prod. 2017, 168, 1381-1388. [CrossRef]

44. Zheng, Y.; Xue, T.; Zhang, Q.; Geng, G.; Tong, D.; Li, X.; He, K. Air quality improvements and health benefits from China's clean air action since 2013. Environ. Res. Lett. 2017, 12, 114020. [CrossRef]

45. Guo, H.; Ding, A.J.; So, K.L.; Ayoko, G.; Li, Y.S.; Hung, W.T. Receptor modeling of source apportionment of Hong Kong aerosols and the implication of urban and regional contribution. Atmos. Environ. 2009, 43, 1159-1169. [CrossRef]

46. Yuan, Z.B.; Yu, J.Z.; Lau, A.K.H.; Louie, P.K.K.; Fung, J.C.H. Application of positive matrix factorization in estimating aerosol secondary organic carbon in Hong Kong and its relationship with secondary sulfate. Atmos. Chem. Phys. 2006, 6, 25-34. [CrossRef]

47. Hedley, A.J.; Wong, C.M.; Thach, T.Q.; Ma, S.; Lam, T.H.; Anderson, H.R. Cardiorespiratory and all-cause mortality after restrictions on sulphur content of fuel in Hong Kong: An intervention study. Lancet 2002, 360, 1646-1652. [CrossRef]

48. Peters, J.; Hedley, A.J.; Wong, C.M.; Lam, T.H.; Ong, S.G.; Liu, J.; Spiegelhalter, D.J. Effects of an ambient air pollution intervention and environmental tobacco smoke on children's respiratory health in Hong Kong. Int. J. Epidemiol. 1996, 25, 821-828. [CrossRef]

49. Han, L.; Sun, Z.; He, J.; Hao, Y.; Tang, Q.; Zhang, X.; Zheng, C.; Miao, S. Seasonal variation in health impacts associated with visibility in Beijing, China. Sci. Total Environ. 2020, 730, 139149. [CrossRef] [PubMed]

50. Huang, W.; Tan, J.; Kan, H.; Zhao, N.; Song, W.; Song, G.; Chen, G.; Jiang, L.; Jiang, C.; Chen, R.; et al. Visibility, air quality and daily mortality in Shanghai, China. Sci. Total Environ. 2009, 407, 3295-3300. [CrossRef]

51. Lee, J.Y.; Jo, W.K.; Chun, H.H. Long-term trends in visibility and its relationship with mortality, air-quality index, and meteorological factors in selected areas of Korea. Aerosol Air Qual. Res. 2014, 15, 673-681. [CrossRef]

52. Tian, L.; Hossain, S.R.; Lin, H.; Ho, K.F.; Lee, S.C.; Ignatius, T.S. Increasing trend of primary NO 2 exhaust emission fraction in Hong Kong. Environ. Geochem. Health 2011, 33, 623-630. [CrossRef]

53. Xue, L.; Wang, T.; Louie, P.K.; Luk, C.W.; Blake, D.R.; Xu, Z. Increasing external effects negate local efforts to control ozone air pollution: A case study of Hong Kong and implications for other Chinese cities. Environ. Sci. Technol. 2014, 48, 10769-10775. [CrossRef] [PubMed]

54. IQAir. 2019 World Air Quality Report; IQAir Group: Goldach, Switzerland, 2020.

55. HKEPD. Hong Kong's Air Quality Objectives. 2014. Available online: https://www.epd.gov.hk/epd/english/environmentinhk/ air/air_quality_objectives/air_quality_objectives.html (accessed on 3 June 2021).

56. WHO. Air Quality Guidelines for Particulate Matter, Ozone, Nitrogen Dioxide and Sulfur Dioxide, Global Update; World Health Organization: Geneva, Switzerland, 2005.

57. HKEPD. Compliance Status of Air Quality Objectives in 2019. 2020. Available online: https://www.epd.gov.hk/epd/sites/ default/files/epd/english/environmentinhk/air/air_quality_objectives / files/compliance_eng.pdf (accessed on 3 June 2021).

58. Brimblecombe, P.; Ning, Z. Effect of road blockages on local air pollution during the Hong Kong protests and its implications for air quality management. Sci. Total Environ. 2015, 536, 443-448. [CrossRef] [PubMed]

59. Kan, C. Expanding pedestrian zones can solve Hong Kong's air pollution problems. South China Morning Post, 27 October 2015; P2.

60. Bickerstaff, K.; Walker, G. Public understandings of air pollution: The 'localisation' of environmental risk. Glob. Environ. Chang.-Hum. Policy Dimens. 2001, 11, 133-145. [CrossRef] 